\title{
Hrad Divín vo svetle nových výskumov ${ }^{1}$
}

\author{
TOMÁš JANURA - MichaL ŠIMKOVIC - EVA FoTTOVÁ \\ Historický ústav Slovenskej akadémie vied v Bratislave, \\ Mgr. Michal Šimkovic s.r.o., Zvolen, \\ Archeologický ústav Slovenskej akadémie vied v Nitre
}

\section{Divín Castle in the light of new research}

Abstract: The lords of Lučenec probably founded the castle sometime at the turn of the $13^{\text {th }}$ and $14^{\text {th }}$ centuries. It belonged to their descendants until the end of the $15^{\text {th }}$ century, when the Ongor family became the new owners. After 1512, the Balassa family became the new owners. Throughout the middle ages, Divín remained a small aristocratic castle called mantle type with simple fortification. Its significant expansion and improvement of the fortifications was associated only with Sigismund and John Balassa, when due to the Ottoman danger, the population of the Novohrad region had to participate in the modernization of Divín, according to the adopted laws. Despite this effort, the castle fell into the hands of the Ottomans in the years 1575-1593 and became the northernmost occupied castle in Hungary. After the conquest of the castle by Habsburg troops, Divín returned to the hands of the Balassa family, who in the $17^{\text {th }}$ century took care of the expansion of the living space and planned further improvements of the fortifications.

Keywords: Divín castle, lords of Lučenec, Dezsőfi family, Balassa family, Ottomans.

DOI: https://doi.org/10.24040/ahn.2020.23.02.05-28

V odbornej historickej literatúre sa zatial' hradu Divín nevenovala žiadna samostatná štúdia alebo publikácia. Boli zverejnené predovšetkým výsledky čiastkových bádaní z obdobia stredoveku. Základné údaje o vzniku a majitel'och hradu do roku 1457 na mad'arskej strane publikovali Erik Fügedi a Pál Engel. Zo slovenských vedcov stručnú stat' o celom stredovekom období spracovala Daniela Dvořáková. Spôsob, akým sa Balassovci dostali k vlastníctvu Divína ozrejmila Zsuzsana Hermann. Najrozsiahlejší text o historickom vývoji majitel’ov za celý

\footnotetext{
1 Táto práca bola podporovaná Agentúrou na podporu výskumu a vývoja na základe Zmluvy č. APVV-17-0063. Historická čast' textu Tomáša Januru bola po roku 2012 doplnená o d'alšie údaje a vznikla v rámci projektu APVV-17-0398 Na ceste $k$ modernej spoločnosti. Tri storočia novoveku a grantu VEGA 2/0101/17 Spoločnost' raného novoveku identity, konflikty, interakcie.
} 
stredovek publikoval Tomáš Sitár v rámci historickej topografie Novohradu. ${ }^{2}$ Na zbrane a výzbroj hradu v roku 1666 sa zameral Jozef Orság. Éva Szirácsik upriamila pozornost' na hospodárske dejiny panstva. ${ }^{3}$ Stavebno-historického vývoja Divína sa čiastočne dotkol príspevok Mikuláša Mózera a Ladislava Šáškyho. Neskôr v encyklopedických prácach hrad v samostatnom hesle priblížili Michal Šimkovic a Miroslav Plaček. Tieto stručné hodnotenia doplnila monografia venovaná pamiatkam Divína. ${ }^{4}$ Po roku 2012 sa na hrade rozbehli záchranné práce, ktorých súčast'ou bol aj postupný architektonicko-historický a archeologický výskum.

Prvá priama písomná zmienka o hrade Divín sa zachovala z roku 1329, a preto nebolo možné na základe listinného materiálu presne stanovit', kedy hrad vznikol a kto ho vybudoval. Avšak, na základe spomínanej listiny a dokumentu z roku 1347 sa dali čiastočne rekonštruovat' udalosti pred rokom 1329. Na začiatku druhej tretiny 14. storočia sa v listinách spomínalo rozdelenie Divína medzi bratov Tomáša a Štefana, príslušníkov rodu z Lučenca (Losonczy), z čoho jednoznačne vyplynulo, že hrad i panstvo vznikli už v časoch ich otca Dionýza z Lučenca, písomne doloženého v rokoch 1275 až $1294 . .^{5}$ Historik Pál Engel vo svojej práci uviedol ako možného stavebníka aj starého otca spomenutých bratov Dionýza, uhorského palatína v rokoch 1235 - 1240, ktorý padol v boji proti Tatárom v roku $1241 .^{6}$

\footnotetext{
2 FÜGEDI, Erik: Vár és társadalom a 13 - 14. századi Magyarországon. Budapest : Akadémiai Kiadó, 1977, s. 149; ENGEL, Pál: Magyarország világi archontológiája 1301 1457. [DVD-ROM] Budapest : Arcanum, 1996, V. Várnagyok és várbirtokosok, Divény, szlk. Divín (Nógrád m., ma Sl.); HERMANN, Zsuzsanna: Miképp került Divény vára a Balassák kezére? In: Levéltári Közlemények. tom. 63. vol. 1 - 2, 1992, s. 61 - 68; SITÁR, Tomáš: Osídlenie Novohradskej stolice v stredoveku. Krná : Miloš Hric, Mesto Lučenec, 2019 , s. $677-679$.

3 ORSÁG, Jozef: Inventár zbraní a výzbroje Divínskeho hradu v roku 1666. In: Vlastivedný časopis. tom. 36. vol. 4, 1987, s. 179 - 181; SZIRÁCSIK, Éva: Divínske panstvo Imricha Balašu (Balassa) podl’a urbára z roku 1660. In: Zborník z medzinárodnej konferencie Modrý Kameň, jún 2012. Rod Balašovcov v 13. až 19. storočí. zost. H. Ferencová a E. Antolová, Modrý Kameň : Slovenské národné múzeum - Múzeum bábkarských kultúr a hračiek Modrý Kameň, 2013, s. 374 - 400.

${ }^{4}$ MÓZER, Mikuláš - ŠÁŠKY, Ladislav: Z minulosti Divína a jeho pamiatok. In: Vlastivedný časopis. tom. 19. vol. 3, 1970, s. 98 - 106; ŠIMKOVIC, Michal: Hrad Divín. In: BURAN, Dušan et al.: Gotika. Dejiny slovenského výtvarného umenia. Bratislava : Slovenská národná galéria, 2003, s. 584; PLAČEK, Miroslav: Divín. In: PLAČEK, Miroslav - BÓNA, Martin: Encyklopédia slovenských hradov. Bratislava : SLOVART, 2007, s. 107 - 109.

5 VARJÚ, Elemér (ed.): Oklevéltár a Tomaj nemzetségbeli losonczi Bánffy család történetéhez I. 1214 - 1457. Budapest : Hornyánszky Viktor Könyvnyomdája, 1908, listina č. 63, s. 60, 61; listina č. 81, s. 81, 82. Genealogická tabul'ka rodu Losonczi: www.genealogy.euweb.cz/hung/losoncz.html [prístup 5. mája 2020].

${ }^{6}$ ENGEL, P.: Magyarország világi archontológiája, Divény; ZSOLDOS, Attila: Magyarország világi archontológiája 1000-1301. Budapest : MTA Történettudományi Intézete, 2011, s. 
Začiatkom 14. storočia synovia Dionýza z Lučenca - bratia Tomáš, Štefan a Dezső - mali už aj hrad Halič v Novohrade a Idech v Sedmohradsku (zaniknutý hrad Mentő v dnešnej obci Aluniş v Rumunsku). K vybudovaniu Haliča došlo pravdepodobne neskôr a prvotnost' existencie Divína spomedzi troch hradov by dokladal fakt, že si ho bratia ako jediný rozdelili na tretiny. Hlavným dôvodom podielového vlastníctva mohlo byt' zachovanie si časti najstaršieho rodového hradu. V čase otvorených konfliktov medzi najvplyvnejšími šl'achticmi a ústrednou král'ovskou mocou odbojní magnáti v bližšie neurčenom roku, podl'a slov listiny zo 6. júna 1347, zničili a vypálili všetky tri hrady. Pri požiaroch opevnených sídiel sa zničilo i viacero dôležitých listín a práve vtedy asi zanikli najstaršie dokumenty, ktoré by vniesli viac svetla do počiatkov Divína. ${ }^{7}$

Poškodenie Divína nadobudlo pravdepodobne väčšie rozmery, ked'že po opätovnom získaní hradu bratmi Tomášom, Štefanom a Dezsőm z Lučenca došlo k stavebným prácam, čo potvrdila listina z 2. apríla 1329 obsahujúca prvú priamu písomnú zmienku o hrade. $V$ deň datovania listiny sa vašský župan, kastelán hradu Sárvár magister Tomáš, a magister Štefan z Lučenca dohodli na zámene majetkov. Tomáš prenechal tretinu spoločného hradu Divín „s jeho miestom a k nemu sa viažucimi prácami“ Štefanovi do dedičného vlastníctva pod podmienkou, že mu Štefan do 25. júla toho istého roku zaplatí 50 mariek striebra. Tomáš d'alej prenechal Štefanovi tretinu dediny Divín a tretinu "Stepklehoty“ v Novohrade a Štefan za uvedené dve lokality dal Tomášovi do dedičnej držby celú sedmohradskú dedinu Dobrin (dnes v Rumunsku). ${ }^{8}$

Štefan z Lučenca sa snažil vo svojich rukách zjednotit' hradné panstvo Divín, ked’že sa tu ako jediný z bratov usadil a pokračoval v prestavbe hradu ako svojho sídla. Z listín sa dal sledovat' iba proces získania podielov z panstva od brata Tomáša z Lučenca. Dňa 9. júla 1335 potvrdil král Karol Róbert zámennú dohodu medzi oboma bratmi. Tomáš vtedy prenechal svoje d'alšie podiely na panstve - celé dediny Mikušovce, Vidiná, Vel'ká Ves a podiely v Lučenci, Divíne a „Zubleha$t a^{\prime \prime 9}$ - vrátane príjmov z t’ažby zlata v okolitých horách - bratovi Štefanovi. Tomáš za svoje novohradské podiely získal od Štefana pät'

19. Genealogická tabul'ka rodu Tomaj: www.genealogy.euweb.cz/hung/tomaj.html [prístup 5. mája 2020].

7 VARJÚ, E. (ed.): Oklevéltár Bánffy család I, listina č. 63, s. 60, 61; listina č. 127, s. 150. Genealogická tabul'ka rodu Losonczi: www.genealogy.euweb.cz/hung/losoncz.html [prístup 5. mája 2020].

${ }^{8}$ VARJÚ, E. (ed.): Oklevéltár Bánffy család I, listina č. 63, s. 60, 61. Stepklehotu sa nepodarilo lokalizovat' ani Tomášovi Sitárovi. SITÁR, T.: Osídlenie Novohradskej stolice, s. 510.

${ }^{9}$ Podl'a T. Sitára ide o zaniknutú dedinu, totožnú so Stepklehotou. Podl'a: SITÁR, T.: Osídlenie Novohradskej stolice, s. 510. 
celých dedín v stolici Vnútorný Solnok a podiely v dvoch dedinách v Sabolčskej stolici. ${ }^{10}$

Napriek úsiliu Štefana z Lučenca zjednotit' panstvo Divín v rukách jedného rodového príslušníka došlo pravdepodobne po jeho smrti a zisku d'alších panstiev hlavne na území Sedmohradska k opätovnému vytvoreniu spoločného rodového vlastníctva Divína. Mohlo to vyjadrovat' snahu rozrastajúceho sa rodu $\mathrm{z}$ Lučenca, $\mathrm{z}$ ktorého sa vyčlenili rody Bánffy a Dezsőfi, spoločne sa starat' o ich najstarší hrad. Druhou možnost'ou bol presun hlavných sídiel do Sedmohradska a nepotrebnost' Divína ako samostatnej rezidencie pre konkrétneho člena rodu.

Pre stavbu hradu si jeho zakladatelia vybrali vrchol skalnatého výbežku nad Tomanovským potokom asi dva kilometre od dial'kovej obchodnej cesty zo Zvolena do Novohradu. Najstarší hrad mal jednoduchú podobu. Základ obrany tvorila vysoká hradba s hrúbkou okolo 2,4-2,7 m a výškou takmer 11 m zakončená cimburím (obr. 1, 2, 3). Masívny múr vymedzujúci pôvodný hrad v tvare nepravidelného mnohouholníka pretrval všetky neskoršie prestavby a niektoré jeho úseky dodnes stoja v pôvodnej výške (obr. 3). Podoba vnútornej zástavby pôvodného hradu bola dlho nejasná. Zásadný posun v poznaní jej podoby a postupného vývoja priniesol až archeologický výskum. V suterénoch neskorogotického južného paláca sa podarilo zistit’ základy pôvodnej, zrejme trojpriestorovej palácovej stavby pristavanej k južnému úseku hradbového múru. Bezprostredne vedl'a nej sa odkryla pôvodná vstupná brána do hradu (obr. 2). Dominantný obranný múr chrániaci vnútorné stavby radí Divín medzi hrady s tzv. plášt'ovou hradbou. Hrady tohto typu sú početne zastúpené predovšetkým v českých krajinách a na Morave, kde si ich stavali ako svoje opevnené sídla príslušníci šlachty na konci 13. a v prvej polovici 14. storočia. ${ }^{6}$ Na našom území má podobný typ šlachtickej rezidencie menej početné zastúpenie. Popri Divíne ho reprezentujú hrady Hrušov a Parič v Trebišove.

Ešte v priebehu stredoveku prešiel hrad rozsiahlou prestavbou, ktorá úplne zmenila jeho vnútorné usporiadanie. V kontexte písomných prameňov môže íst' o rekonštrukciu po jeho rozsiahlom poškodení, ktoré podl'a listín môžeme datovat' pred rok 1347. Významnou zmenou bol zánik pôvodného paláca na južnej strane, ktorý nahradila nová stavba pri severnom úseku hradby (obr. 2). Jej výstavba sa spájala so zamurovaním pôvodnej vstupnej brány a výrazným navýšením terénu nádvoria. Nový vstup vznikol na východnej strane. Chránila ho hranolová bránová veža so stúpajúcim dreveným mostom osadeným na murovaný pilier.

10 VARJÚ, E. (ed.): Oklevéltár Bánffy család I, listina č. 81, s. 81, 82. 
Stav kolektívneho vlastníctva Divína a jeho pozemkového príslušenstva potvrdila del'ba z 13. októbra 1393 uskutočnená v čase po smrti chorvátsko-slavónsko-dalmátskeho bána Dionýza z Lučenca, syna spomínaného vašského župana Tomáša z Lučenca. Dionýz okrem rozsiahlej domény v Sedmohradsku vlastnil na Divínskom panstve polovicu hradu, celé dediny Gregorova Vieska, „Bedehaza“,11 Podrečany, Kotmanova Lehota (dnes Kotmanová), Cinobaňa, Mýtna, Budiná, „Stepklehota“, podiely v Lučenci, Divíne, „Bokuane“,12 mýto v Dobroči a výnosy zo zlatých baní. Sedmohradská držba sa rozdelila medzi jednotlivcov, ale celý Dionýzov divínsky podiel ostal v spoločných rukách jeho synov Petra, Ladislava a Juraja z Lučenca, príslušníkov formujúceho sa rodu Bánffy, a príslušníkov rodu Dezsőfi - sikulského župana Mikuláša a jeho synovca Jána, syna a vnuka vyššie uvedeného Dezsőa z Lučenca. ${ }^{13}$

Z predošlej listiny jednoznačne vyplynulo, že druhú polovicu hradu s d'alšími bližšie nemenovanými dedinami držali vo svojich rukách synovia vyššie uvedeného Štefana z Lučenca - dalmátsko-chorvátskoslavónsky bán Ladislav z Lučenca (†1395) a mačviansky bán Štefan z Lučenca (†1395). Pravdepodobne išlo o dediny, ktoré sa spomínali v roku 1417 v spoločnom vlastníctve synov bána Ladislava, ktorí zdedili majetok aj po bezdetnom strýkovi Štefanovi. Možno teda predpokladat', že druhú polovicu domínia tvorili podiely v Lučenci a celé dediny Vidiná, Ružiná, Lehôtka, Poddivín (dnes Divín), Horný Tuhár (dnes miestna čast' Tuhára), Dolný Tuhár (dnes miestna čast' Tuhára), Praha, Tomášovce, Mašková, „Rachfalua“,14 Jelšovec, Trebel'ovce a Lupoč. Avšak, podobne ako v prípade Bánffyovcov a Dezsőfiovcov, tak aj pre šl'achticov z Lučenca, ktorí začali používat' po vzore svojich príbuzných nové rodové priezvisko Losonczi, predstavoval Divín len okrajový sídelný priestor, ked’že držali viaceré hrady v Sedmohradsku a Slanec v Abovskej stolici. ${ }^{15}$

\footnotetext{
11 Podl’a Dezsőa Csánkiho ide o zaniknutú lokalitu medzi Gregorovou Vieskou a Podrečanmi. CSÁNKI, Dezső: Magyarország történelmi földrajza a Hunyadiak korában I. kötet. Budapest : Kiadja a Magyar Tudományos Akadémia, 1890, s. 95. T. Sitár lokalitu nevie identifikovat'. Uvádza, že išlo o starší názov niektorej z okolitých dedín. SITÁR, T.: Osídlenie Novohradskej stolice, s. 136.

12 Podl'a T. Sitára ide o zaniknuté sídlo Bukovany v chotári Točnice. SITÁR, T.: Osídlenie Novohradskej stolice, s. 164.

13 VARJÚ, E. (ed.): Oklevéltár Bánffy család I, listina č. 322, s. 451 - 453. Genealogická tabul'ka rodu Losonczi a Dezsőfi: www.genealogy.euweb.cz/hung/losoncz.html, www.genealogy.euweb.cz/hung/dezsofi.html [prístup 5. mája 2020].

14 Podl'a T. Sitára ide o samotu Rácka, ktorá dnes tvorí súčast' Haliče. SITÁR, T.: Osídlenie Novohradskej stolice, s. 464.

${ }^{15}$ MÁLYUSZ, Elemér - BORSA, Iván (eds.): Zsigmondkori oklevéltár VI. (1417 - 1418). Budapest : Magyar Országos Levéltár kiadványai, 1999, listina č. 259, s. 120. Genealogická tabul'ka rodu Losonczi: www.genealogy.euweb.cz/hung/losoncz.html [prístup 5. mája 2020].
} 
Po smrti král'a Albrechta Habsburského sa v krajine stupňovala anarchia v dôsledku zápasu medzi stúpencami dvoch král'ov Vladislava I. a Ladislava Pohrobka. Chaos pokračoval i po smrti Vladislava I., ked’že detský král' nemal reálnu šancu ovplyvnit’ vývoj v krajine a jeho záujmy zastupoval český velitel' Ján Jiskra. Jeho kasteláni napádali majetky novohradskej a hontianskej šl'achty, a preto možno predpokladat', že Divínske panstvo sa mohlo stat' terčom útokov Jiskrovho kastelána zo Zvolena. Situáciu mala vyriešit' mierová dohoda zo 17. septembra 1442 medzi predstavitel'mi šlachty Novohradu a Hontu s Jánom Jiskrom o zastavení vzájomných lúpežných prepadov. ${ }^{16}$

Po odchode Jána Jiskru z územia Zvolenskej stolice a banských miest sa z jeho bývalých žoldnierov stali potulní vojaci - bratríci, ktorí poobsadzovali viaceré hrady alebo si založili menšie opevnenia v Hornom Uhorsku a znepokojovali odtial' okolie. V prípade Divína sa nezachovali písomné dôkazy o obsadení hradu bratríkmi, ale na základe listiny zo 7. októbra 1460 vieme, že susedné „castellum“ Ozdín s malým panstvom okupovali. Situácia v krajine sa začala upokojovat’ až po nástupe král'a Mateja na trón. Ned’aleký Ozdín oslobodil Imrich Zápol'ský (zo Zapolje, Szapolyai) a čiastočne aj vyplatil peniazmi miestnu posádku. ${ }^{17}$

Spoločné vlastníctvo panstva Divín rodmi Losonczi, Dezsőfi a Bánffy sa po turbulentnom období bojov s bratríkmi pravdepodobne zmenilo a jedinými držitel'mi sa stali viacerí členovia rodu Dezsőfi. Z obsahu listiny z roku 1473 vyplynulo, že hrad sa ako celok ocitol v rukách Jána Dezsőfiho, syna vyššie spomínaného Jána Dezsőfiho. K podielovým vlastníkom panstva z rozhodnutia král'a Mateja z 8. októbra 1467 pribudol uhorský palatín v rokoch 1458 - 1484 Michal Orzág (Országh) a jeho synovia Ján, Gašpar a Ladislav. Darovanú čast’ predstavovali celé dediny „Bukowan“,18 Gregorova Vieska, Kotmanova Lehota a podiely v dedinách Lučenec, Bušince, Trebel'ovce, Bol'kovce, Točnica, Tomášovce, Podrečany, Uderiná, Mýtna, Podhradie (dnes Divín), Budiná a Polichno. Panovník donáciu odôvodnil tým, že sa bratia Ladislav a Žigmund Dezsőfiovci, pravnuci vyššie spomenutého sikulského župana Mikuláša Dezsőfiho, zúčastnili vojenského odporu sedmohradského

\footnotetext{
${ }^{16}$ Magyar Nemzeti Levéltár - Országos Levéltára Budapest (d’alej MNL - OL), fond (d’alej f.) Diplomatikai Fényképgyűjtemény (U szekció), Szlovákia, Štátny archív Banskej Bystrici, pobočka Kremnica, signatúra (d’alej sign.) DF 249 997. Listinu uverejnil v plnom znení Pál Tóth-Szabó. TÓTH-SZABÓ, Pál: A cseh-huszita mozgalmak és uralom története Magyarországon. Budapest : Hornyánszky Viktor cs. és kir. udvari Könyvnyomda, 1917, listina č. XXVIII, s. $378-380$.

17 MNL - OL, f. Diplomatikai Levéltár (d'alej DL) (Q szekció), Családi levéltárak (P szekcióból), Balassa család (Q 22), sign. DL 65921.

18 Podl'a T. Sitára ide o zaniknuté sídlo Bukovany v chotári Točnice. SITÁR, T.: Osídlenie Novohradskej stolice, s. 164.
} 
vojvodu Jána Groffa. ${ }^{19}$ V celom texte donácie ani slovom nezmienili Orzágov podiel z hradu Divín, čo jednoznačne vyvrátilo publikovaný údaj, že od roku 1467 bol majitel'om hradu palatín, ${ }^{20}$ ktorý ho v skutočnosti vôbec nevlastnil a nadobudol iba podiely na panstve.

Král'ovská donácia pre palatína Michala Orzága oprávňovala kapitulu vo Vacove, aby vykonala uvedenie do vlastníctva - štatúciu, ktorá sa začala 6. novembra 1467, ale v dedine Bušince zástupcovia Blažeja z Ďarmôt, Jána Dezsőfiho a jeho manželky Hedvigy namietli nezákonnost' vovedenia palatína do podielu na Divíne. Kapitula o celej záležitosti informovala panovníka a nariadila, aby sa 13. januára 1468 priamo pred král'a dostavili manželia Dezsőfiovci i Blažej z Ďarmôt. Vládca však ešte pred týmto termínom 1. januára 1468 napísal z Brašova list Jánovi Dezsőfimu, že podiely z hradného panstva Divín daroval palatínovi a požiadal ho, aby pri nasledujúcej štatúcii na hrad pustil palatína alebo jeho zástupcov. ${ }^{21}$

Dezsőfiovci i Blažej z Ďarmôt sa stretnutia s král'om zúčastnili 13. januára 1469 a Matej znovu zopakoval svoje rozhodnutie a zamietol ich neoprávnené st’ažnosti. Dňa 25. februára 1469 král' potvrdil staršiu donáciu z 8. októbra 1467 a 6. marca 1469 nariadil, aby zástupcovia kapituly vo Váci vykonali d’alšiu štatúciu v prospech palatína Michala Orzága. Členovia kapituly voviedli palatína a jeho synov do vlastníctva postupne od 19. do 21. mája 1469. O priebehu štatúcie informovali panovníka 23. mája 1469, čím sa na dlhšie obdobie uzavreli protesty Dezsőfiovcov proti Orzágovcom. ${ }^{22}$

Po smrti Jána Dezsőfiho sa do bližšie nešpecifikovaných problémov dostal jeho syn Michal Dezsőfi (†1494/1495) a výrazne mu pri nich pomáhal Ján Ongor (Hungor, Ungor), ktorý patril do príbuzenstva krála Mateja a rovnako ako palatín Michal Orzág dostal v roku 1467 pre účast' Dezsőfiovcov na vzbure $v$ Sedmohradsku podiel $\mathrm{z}$ hradného panstva Vécs (dnes Brâncovenești v Rumunsku) v stolici Torda. Michal Dezsőfi očakával, že Ongor mu bude pomáhat’ aj v budúcnosti, a preto mu 26. apríla 1473 prenechal do dedičného vlastníctva svoj podiel panstva Divín, ktorý nebol král'om Matejom pred šiestimi rokmi skonfiškovaný. Ongor za svoju pomoc dostal celý hrad Divín a z panstva celú dedinu

\footnotetext{
${ }^{19}$ IVÁNYI, Béla (ed.): Oklevéltár a Tomaj nemzetségbeli losonczi Bánffy család történetéhez II. 1458 - 1526. Budapest : Hornyánszky Viktor Könyvnyomdája, 1928, listina č. 78, s. 93, 94; TÓTH, Norbert - HORVÁTH, Richárd - NEUMANN, Tibor - PÁLOSFALVI, Tamás: Magyarország világi archontológiája 1458 - 1526. I. Főpapok és bárók. Budapest : MTA Bölcsészettudományi Kutatóközpont Történettudományi Intézet, 2016, s. 80. Genealogická tabul'ka rodu Dezsőfi: www.genealogy.euweb.cz/hung/dezsofi.html [prístup 5. mája 2020].

${ }^{20}$ PLAČEK, M.: Divín, s. 107.

${ }^{21}$ IVÁNYI, B. (ed.): Oklevéltár Bánffy család II, listina č. 80, s. 97; listina č. 99, s. 118, 119.

22 IVÁNYI, B. (ed.): Oklevéltár Bánffy család II, listina č. 97, s. 113 - 116; listina č. 98, s. 117; listina č. 102, s. 123, 124.
} 
Kotmanova Lehota a podiely v dedinách Poddivín, "Thomanlehota“,23 Budiná, Polichno, Mýtna, Dobroč, Lovinobaňa, Uderiná, Podrečany, Malé Podrečany (dnes súčast' Podrečian), Gregorova Vieska, Točnica, Tomášovce, Bol'kovce, Lučenec, Bušince, Újlak (dnes miestna čast' mad'arskej obce Vizslás), Kalaputh (dnešná mad’arská obec Kazár), Kürth (zaniknutá lokalita v chotári dnešnej mad'arskej obce Ludányhalászi), Zombor a Nová Ves. ${ }^{24}$ Okrem panstva Divín Ongor prevzal aj Michalove celistvé či podielové majetky na území sedmohradských stolíc Kolož, Torda, Vnútorný Solnok a Küküllő. ${ }^{25}$ Predmetná listina predstavovala presvedčivý dôkaz o tom, že z rúk Dezsőfiovcov hrad priamo prešiel do rúk Jána Ongora a Orzágovci sa nikdy nestali vlastníkmi hradu, ako sa to uvádzalo v doterajšej odbornej literatúre.

Ked' Ján Ongor získal podiely z panstva a celý hrad Divín, patril už k popredným osobnostiam na dvore král'a Mateja. Ako mladík na začiatku Matejovej vlády vstúpil do jeho povestného vojska a v rokoch 1459 - 1464 sa zúčastnil výprav proti Osmanom na území Bosny vrátane dobytia hradov Jajce a Zvornik. V panovníkovej armáde bojoval aj počas vytláčania bratríkov a osobne asistoval pri ich definitívnej porážke 30. januára 1467 v bitke pri Vel'kých Kostol'anoch. V druhej polovici roku 1467 sa stal sedmohradským vojvodom a už na prelome rokov 1467/68 sprevádzal vládcu na neúspešnej výprave proti moldavskému kniežat'u Štefanovi. Po vpáde pol'ských vojsk do Uhorska na jeseň 1471 sa zaslúžil o porážku Poliakov a ich stiahnutie sa z král'ovstva. ${ }^{26}$

Vd’aka blízkosti k panovníkovi si mohol Ján Ongor 30. augusta 1473 dovolit' pred kapitulou v Budíne uzavriet' zmluvu o vzájomnom dedení majetkov s Michalom zo Szobu. Kontrakt si totiž vyžadoval král'ovský súhlas, pretože by Matej v prípade vymretia jednej zo strán stratil právo na zoštátnenie ich majetkov z titulu práva na odúmrt'. Avšak král' s prihliadnutím na dlhodobú Ongorovu vernost' a jeho postavenie dvorského familiára 9. novembra 1473 potvrdil platnost' obojstranného do-

\footnotetext{
${ }^{23}$ Podl’a D. Csánkiho ide pravdepodobne o dnešnú dedinu Ružiná. CSÁNKI, D.: Magyarország történelmi földrajza, s. 109. T. Sitár lokalitu presvedčivejšie stotožňuje so sídlom Tomanová v chotári Divína. SITÁR, T.: Osídlenie Novohradskej stolice, s. 579.

${ }^{24}$ Identifikácia lokalít Újlak, Kalaputh, Kürth a Nová Ves vychádza z: CSÁNKI, D.: Magyarország történelmi földrajza, s. 100, 102, 110. Podl'a T. Sitára je Újlak zaniknutá lokalita v chotári Bátonyterenye, Kalaputh zaniknutá lokalita v chotári Rákóczibánye, Kürth zaniknutý Kirt' v chotári Čelár. SITÁR, T.: Osídlenie Novohradskej stolice, s. 287, 310.

${ }^{25}$ IVÁNYI, B. (ed.): Oklevéltár Bánffy család II, listina č. 134, s. 163 - 165; BENKŐ, Elek: A marosvécsi oroszlán. In: Studia Caroliensia. tom. 7, vol. 3 - 4, 2006, s. 320.

${ }^{26}$ MNL - OL, f. DL (Q szekció), Erdélyi országos kormányhatósági levéltárákból (F), Erdélyi kincstári levéltár, Erdélyi fiscalis levéltár (d’alej EFL) (Q 343), sign. DL 16167. TÓTH, N. - HORVÁTH, R. - NEUMANN, T. - PÁLOSFALVI, T.: Magyarország világi archontológiája I, s. 85; HOMOL'A, Tomáš: Na vzostupe moci. Zahraničná politika Mateja Korvína v stredoeurópskom priestore v rokoch 1458 - 1471. Bratislava : Veda, 2019, s. 70, 80.
} 
jednania a vzdal sa do budúcnosti $\mathrm{v}$ mene svojom i svojich nástupcov všetkých král’ovských práv na predmetné vlastníctvo. ${ }^{27}$

Pred kapitulou v Budíne sa uvedeného 30. augusta 1473 osobne stretli Ján Ongor a jeho brat Mikuláš Ongor s Michalom zo Szobu. Súrodenci Ongorovci zastupovali tiež svojho príbuzného Ladislava Árku z Densuşu. Spolu s Michalom zo Szobu sa všetci štyria vzájomne vyhlásili za adoptívnych bratov. V prípade vymretia jednej zo zmluvných strán mohla tá druhá zdedit’ celý jej majetok. Navyše každá zo strán nadobudla dispozičné právo l'ubovol'ne nakladat' so svojim doterajším vlastníctvom. Nehnutel'nosti Ongorovcov sa v čase uzavretia kontraktu rozprestierali na území stolíc Doboka, Torda, Kolož, Temeš a Hunyad. V Novohradskej stolici tvoril Ongorovské majetky celý hrad Divín a k nemu prináležiace podiely $\mathrm{v}$ zemepanskom meste Lučenec, čiastky v dedinách Poddivín, Tomášovce, Točnica, Podrečany, Gregorova Vieska, Mýtna, Uderiná, Lovinobaňa, Kotmanova Lehota, Dobroč, Píla, Budiná, Polichno a celá dedina Bušovce. Držba Michala zo Szobu ležala v stoliciach Bihar, Doboka, Hont, Novohrad, Sabolč a Šomod'. Ján Ongor takúto vel'korysú dohodu odôvodnil tým, že chcel zabezpečit', aby sa nezabudlo „na bratskú lásku“, ktorá ho spájala s už nebohým Michalovým otcom Petrom zo Szobu, bosnianskym bánom v rokoch 1465 1466 a dalmátsko-chorvátskym bánom v rokoch 1459 a $1466 .{ }^{28}$

Ján Ongor sa aj po získaní hradu Divín angažoval vo vojenských t’aženiach král'a Mateja. V roku 1476 sa zúčastnil d'alšej protiosmanskej výpravy, počas ktorej sa aktívne zapojil do obliehania pevnosti Šabac v Srbsku. Po vpáde vojsk cisára Fridricha III. v roku 1477 do král'ovstva bojoval proti votrelcom a následne sa spolupodiel'al na obsadzovaní Dolného Rakúska uhorským panovníkom. ${ }^{29}$

Po smrti král'a Mateja stratili potomkovia Michala Orzága svojho ochrancu a ich politický vplyv začal upadat'. Preto už 22. januára 1491 príslušníci rodov Losonczi, Dezsőfi a Bánffy protestovali pred konventom v Lelesi proti rozhodnutiu Mateja o darovaní pred rokmi skonfiškovaných majetkov v príslušenstvách troch sedmohradských hradov a uhorského hradu Divín. Od svojho protestu očakávali od nového panovníka Vladislava II. zrušenie starého rozhodnutia, čím by oslabení Orzágovci prišli o niekdajšie konfiškáty. ${ }^{30}$

\footnotetext{
${ }^{27}$ MNL - OL, f. DL (Q szekció), EFL (Q 343), sign. DL 16167.

${ }^{28}$ MNL - OL, f. DL (Q szekció), EFL (Q 343), sign. DL 16 167; f. DL (Q szekció), Erdélyi országos kormányhatósági levéltárakból (F), KKOL, Protocolla (d’alej KKOLP) (Q 333), sign. DL 36 404, pagina (d’alej pag.) 174, 175. TÓTH, N. - HORVÁTH, R. - NEUMANN, T. PÁLOSFALVI, T.: Magyarország világi archontológiája I, s. 139.

${ }^{29} \mathrm{MNL}$ - OL, f. DL (Q szekció), EFL (Q 343), sign. DL 16167.

30 IVÁNYI, B. (ed.): Oklevéltár Bánffy család II, listina č. 262, s. 295.
} 
Spojené úsilie troch rodov zostalo neúspešné, a preto sa 15 . júna 1495 v Budíne konalo stretnutie rodov Dezsőfi a Bánffy, kde sa dohodli ustúpit' z pozície spochybňovania niekdajšieho král’ovského rozhodnutia. Uzniesli sa, že vlastníctvo ich predkov na území sedmohradských stolíc a panstva Divín v Uhorsku, ktoré boli zhabané a nachádzali sa v cudzích rukách, mal vykúpit' Mikuláš Bethlen. Ani táto dohoda ale nepriniesla reštitúciu bývalých rodových majetkov. ${ }^{31}$

Orzágovci sa mohli spoločného postupu obávat', a preto zrejme nechceli riskovat' stratu podielov z panstva Divín bez finančného odškodnenia. Pravdepodobne sa dohodli s Jánom Ongorom, ktorý mohol orzágovský podiel z panstva kúpit'. Listina o prevode podielu sa nezachovala a možno iba predpokladat', že sa tak udialo pred rokom 1498, ked’že vtedy sa už pri del'be vlastníctva rodu Orzág ani slovom nezmienili o Divíne. ${ }^{32}$

Ján Ongor sa vynasnažil zjednotit' celé panstvo po takmer viac ako dvesto rokoch od jeho založenia, a preto sa dohodol s Dezsőfiovcami na získaní ich zvyšných podielov. V scel'ovaní pokračovali i dvaja Ongorovi synovia Ján (†1506) a Mikuláš Ongorovci a 22. apríla 1499 dostali od vdovy po Ladislavovi Dezsőfim jej podiel z manželových hradných panstiev Divín v Novohrade a Vécs v stolici Torda. V prípade Ladislavovej vdovy išlo o majetok získaný ako obvenenie, čiže vlastníctvo udelené manželom pri príležitosti uzavretia manželstva, alebo neskôr. ${ }^{33}$

Na hrade sa podarilo zistit' viacero stavebných úprav, ktoré je možné rámcovo datovat' do 15 . storočia. Pravdepodobne v polovici 15 . storočia vtedajší majitelia realizovali d'alšiu rozsiahlu prestavbu palácových budov. Staršie obytné trakty nahradilo podpivničené palácové krídlo rozložené pozdíž južnej a juhovýchodnej strany opevnenia (obr. $4: 2$ ). Dnes sa z neho zachovali pozostatky rozsiahleho suterénu zaklenutého tehlovou klenbu. Adaptáciu obytných budov doplnilo čiastočné zlepšenie opevnenia. K vstupnej bráne sa pripojil nový okruh opevnenia tvorený parkánovým múrom (obr. 4:5), ktorý po vonkajšom obvode opevnenia vymedzoval približne pät' metrov široký priestor. Jeho vonkajšiu stranu lemovala priekopa vysekaná do skaly na úpätí hradby.

Napriek neskorogotickým prestavbám až do konca stredoveku Divín ostal malým šl'achtickým hradom s jednoduchým opevnením. Je možné, že podobne ako na iných hradoch ešte pred protiosmanskými vojnami mohlo vzniknút' na nižšie položenej terase opevnené predhradie chrá-

\footnotetext{
31 IVÁNYI, B. (ed.): Oklevéltár Bánffy család II, listina č. 265, s. 324 - 326.

${ }^{32}$ MNL - OL, f. DL (Q szekció), Családi levéltárak (P szekcióból), Orczy család (d’alej OCs) (Q 144), sign. DL 73538.

33 IVÁNYI, B. (ed.): Oklevéltár Bánffy család II, listina č. 287, s. 355; BENKŐ, E.: A marosvécsi oroszlán, s. 320.
} 
niace hospodárske zázemie panského sídla. Po jeho stavbách a opevnení sa však nezachovali žiadne stopy a túto otázku pomôže vyriešit' až budúci archeologický výskum.

Obaja súrodenci Ongorovci na začiatku 16. storočia nemali mužských dedičov, čo pre stále žijúceho Michala zo Szobu mohlo znamenat', že sa nakoniec podl'a zmluvy z 30. augusta 1473 stane dedičom ongorovských majetkov. Ked’že medzičasom prišlo k výmene na uhorskom tróne, požiadali bratia Ongorovci a Michal zo Szobu král'a Vladislava II., aby uvedený kontrakt potvrdil. Panovník dohodu o vzájomnom dedení 13. decembra 1502 schválil a rovnako ako Matej Korvín sa vzdal do budúcnosti všetkých svojich král'ovských práv. ${ }^{34}$

Začiatkom 16. storočia došlo k takmer úplnému zjednoteniu Divína, čo doložila listina král'a Vladislava II. z 12. decembra 1505. Panovník v nej dodatočne schválil rozhodnutie Jána Ongora, ktoré urobil 7. septembra 1505 pred konventom v Šahách, kde celý hrad Divín a celé dediny Poddivín, Tomášovce, Točnica, Podrečany, Gregorova Vieska, „Strawystha",35 Uderiná, Lovinobaňa, Kotmanova Lehota, Dobroč, Mýtna, Píla, Budiná, Polichno a podiely v zemepanskom meste Lučenec odkázal svojej manželke Dorote, dcére Mateja Malého z Poroszló. Ked’že z manželstva nevzišlo žiadne mužské potomstvo, mohla Dorota s odkázaným majetkom naložit' podl'a vlastného uváženia. Okrem Divína od manžela získala podobné práva aj na hrad Vécs a príslušné panstvo. ${ }^{36}$

Ked' na jeseň 1506 Ján Ongor zomrel, zostala po ňom vdova Dorota z Poroszló a jeho slobodná dcéra Katarína Ongorová. Michal zo Szobu sa medzitým v rokoch 1503 - 1510 stal hontianskym županom, využil príležitost' a svojimi l'ud'mi obsadil hrad Divín. Michal tým vedome porušil ustanovenia zmluvy, že každá zo strán môže odkázat' svoj majetok tretím osobám. Dorota sa na jeho počínanie st’ažovala, a preto sa 13. apríla 1507 stretla s Michalom v novohradskej dedine Petény, kde mal svoju stálu rezidenciu. Schôdzka sa konala aj za prítomnosti novohradského župana v rokoch 1505 - 1510, protonotára krajinského sudcu a sedmohradského vojvodu v rokoch 1502 - 1515, magistra Štefana z Verbovca. ${ }^{37}$

\footnotetext{
${ }^{34}$ MNL - OL, f. DL (Q szekció), EFL (Q 343), sign. DL 16 167; KKOLP (Q 333), sign. DL 36404 , pag. $173-177$.

35 Podl'a D. Csánkiho ide asi o lokalitu v blízkosti obcí Podrečany, Gregorova Vieska alebo Uderiná. CSÁNKI, D.: Magyarország történelmi földrajza, s. 108. T. Sitár stotožnil túto lokalitu so sídlom Strážka v chotári Podrečian. SITÁR, T.: Osídlenie Novohradskej stolice, s. 512.

${ }^{36}$ MNL - OL, f. DL (Q szekció), EFL (Q 343), sign. DL 16 167; OCs (Q 144), sign. DL 73540.

37 TÓTH, N. - HORVÁTH, R. - NEUMANN, T. - PÁLOSFALVI, T.: Magyarország világi archontológiája I, s. 88, 91; TÓTH, Norbert - HORVÁTH, Richárd - NEUMANN, Tibor - PÁLOSFALVI, Tamás - KOVÁCS, András: Magyarország világi archontológiája 1458 - 1526. II. Megyék. Budapest : MTA Bölcsészettudományi Kutatóközpont Történettudományi Intézet, 2017, s. 125, 163.
} 
Sporné strany sa dohodli na kompromise. Dorota z Poroszló prenechala všetky manželove dedičné majetky na území Sedmohradska a Uhorska s výnimkou „castella“ Frumuşeni v Aradskej stolici Michalovi zo Szobu. Na druhej strane ale nehnutel'nosti, ktoré jej nebohý muž kúpil, prejdú do vlastníctva jej dcéry Kataríny Ongorovej. Ked’že Dorota získala Divín na základe manželovho testamentu, musel hontiansky župan hrad a panstvo vrátit’ vdove a jej dcére do času, kým nebudú za domínium odškodnené. Dňa 16. apríla 1507 Štefan z Verbovca prišiel na Divín a zobral odtial' truhlicu s písomnost'ami. Potom sa 18. apríla dostavil do Dorotinej stálej rezidencie v Bušovciach a prenechal jej listiny, na ktoré mala nárok. Celú záležitost' nakoniec protonotár 1. mája prezentoval pred barónmi krajiny na dvore v Budíne v prítomnosti krajinského sudcu a sedmohradského vojvodu Petra Groffa zo Svätého Jura a Pezinka. ${ }^{38}$

Nakoniec však Divín nezostal v rukách hontianskeho župana, pretože 21. marca 1512 bola pred Petrom Groffom zo Svätého Jura a Pezinka uzavretá d'alšia dohoda. Michal zo Szobu sa totiž chcel odvd'ačit' pravnukovi Blažeja z Ďarmôt, Františkovi st. Balassovi (†1526), za „prejavovanú ochotu a bratskost' od ich mladých čias", a preto v záujme jej pokračovania Katarínu Ongorovú prisl'úbil za manželku jednému z Balassových synov - Wolfgangovi, Františkovi ml. alebo Imrichovi Balassovcom. 0 výbere partnera mal priamo rozhodnút' až ich otec. Po uzavretí a konzumovaní manželstva prejde na Katarínu a jej budúceho muža županov hrad Divín, ale aj Katarínina dievčenská štvrtina zo všetkých otcových majetkov. Rovnako sa Katarína stane dedičkou podielov nebohého otca $\mathrm{v}$ meste Lučenec a podielov $v$ dedinách Bušovce, Poddivín, Tomášovce, Točnica, Podrečany, Gregorova Vieska, Stará Halič, Uderiná, Lovinobaňa, Dobroč, Mýtna, Budiná a Polichno, ale aj celých dedín Píla a Kotmanova Lehota. Okrem toho jej pripadnú majetky na území Csongrádskej stolice. Po Kataríne a jej manželovi mohli dedit’ potomkovia oboch pohlaví. Ak by Katarína a jej budúci muž zomreli ešte pred uzavretím sobáša, vlastníctvo by prevzal František st. Balassa. ${ }^{39}$

Skutočné pozadie kontraktu však odhalila Zsuzsanna Hermann. Na základe rozboru nedatovanej písomnosti vo formulárovej knihe Štefana z Verbovca s čiastočne zašifrovanými menami preukázala, že 14. februára 1511 sa Blažej zo Ságu (dnes Karancsság) vracal zo svadby po úzkej

\footnotetext{
${ }^{38} \mathrm{MNL}$ - OL, f. DL (Q szekció) EFL (Q 343), sign. DL 16167.

${ }^{39}$ MNL - OL, f. DL (Q szekció), KKOLP (Q 333), sign. DL 36 404, pag. 177-179; HORVÁTH, Richárd: „Gradus ad Parnassum“ Ďarmotskí Balašovci v neskorom stredoveku. In: Zborník z medzinárodnej konferencie Modrý Kameň, 2012. Rod Balašovcov v 13. až 19. storočí. zost. H. Ferancová a E. Antolová, Modrý Kameň : Slovenské národné múzeum - Múzeum bábkarských kultúr a hračiek hrad Modrý Kameň, 2013, s. 46.
} 
a zasneženej ceste. Po strete so sprievodom novohradského župana v rokoch 1511 - 1526 Františka st. Balassu došlo k hádke o právo na prednost' pri jej prechode. Roztržka viedla k násiliu a aj samotný Balassa bol zranený. Celá vec sa dostala pred súd, kde sa za Blažeja zo Ságu postavil jeho bratranec Michal zo Szobu. Ani jedna zo strán nechcela, aby sa zvesti o údajnom atentáte rozšírili a celá záležitost’ sa vyriešila odškodnením Balassu v podobe Divína. Zrejme už v marci 1512 sa konala svadba Kataríny Ongorovej s Balassovým synom Františkom ml. Balassom. ${ }^{40}$

V turbulentných časoch po bitke pri Moháči, v ktorej padol aj svokor Kataríny Ongorovej, sa Balassovci pridali na stranu Jána Zápol'ského. Ked' Katarína, zrejme pred novembrom 1535, zomrela ako bezdetná, považoval Ferdinand I. panstvo Divín za svoje vlastníctvo ako odúmrt'. Preto Habsburgovec 13. novembra 1535 udelil Divín s celým jednotným panstvom ostrihomskému arcibiskupovi Pavlovi Várdaymu. ${ }^{41}$ Darovanie však bolo iba formálnou záležitost'ou, pretože žijúci bratia Františka ml. Balassu sa nemienili vzdat' rozl'ahlého imania na hraniciach s ich rodovým Modrým Kameňom. Spojenie oboch domínií by totiž výrazne posilnilo postavenie Balassovcov v Novohradskej stolici.

Zrejme po smrti Kataríny Ongorovej bud' na základe jej testamentu, alebo na úkor svojich príbuzných nadobudol Divín jej švagor, teda brat jej nebohého manžela, Žigmund Balassa (†1559). Okrem podielu na rodovom Modrom Kameni v roku 1530 násilím obsadil premonštrátske kláštorné panstvo Bzovík a v roku 1536 získal aj hrad Diósgyőr, ktorý sa stal jeho hlavným sídlom. Žigmund nadiktoval svoju poslednú vôl'u v prítomnosti viacerých šl'achticov a zástupcov Jágerskej kapituly 20. januára 1559 v Diósgyőri. Na základe Žigmundovho testamentu iba hrad a panstvo Diósgyőr zdedili jeho bratia a synovci. Bzovík prenechal do dedičného vlastníctva svojej manželke Barbore Fánchyovej (†1561) a Divín mala Barbora užívat' doživotne ako venné. Barbora sa usadila na Bzovíku a vd’aka Žigmundovmu rozhodnutiu ho mohla odkázat’ svojmu bratovi Jurajovi Fánchymu. ${ }^{42}$

\footnotetext{
${ }^{40}$ HERMANN, Zs.: Miképp került Divény, s. 61-70; TÓTH, N. - HORVÁTH, R. - NEUMANN, T. - PÁLOSFALVI, T. - KOVÁCS, A.: Magyarország világi archontológiája II, s. 544.

${ }^{41}$ MNL - OL, f. Magyar Kancelláriai Levéltár (d’alej MKL), Libri regii (d'alej LR) 1, pag. 303, 304.

42 Slovenský národný archív, f. Hodnoverné miesto Hronský Beňadik, autentický protokol z rokov 1580 - 1583, littera F, sign. HP 289, pag. 83 - 88; GYULAI, Éva: Žigmund Balaša (†1559), majitel' Diósgyőrského panstva. In: Zborník z medzinárodnej konferencie Modrý Kameň, jún 2012. Rod Balašovcov v 13. až 19. storočí. zost. H. Ferencová a E. Antolová, Modrý Kameň : Slovenské národné múzeum - Múzeum bábkarských kultúr a hračiek hrad Modrý Kameň, 2013, s. 337 - 346; ŽAŽOVÁ, Henrieta: Stredoveké premonštrátske kláštory v slovenskej časti územia bývalého Ostrihomského arcibiskupstva. Trnava : Filozofická fakulta Trnavskej univerzity v Trnave, 2017, s. 89 - 92.
} 
Ked'že Divín Barbora Fánchyová nenadobudla z titulu dedičného vlastníctva, po jej smrti sa na základe neskorších prameňov novohradský hrad dostal hlavne do rúk zvolenského župana a kapitána Jána Balassu (†1577), ktorý od roku 1554 vlastnil aj panstvo (Liptovský) Hrádok, chránené od vpádu Osmanov. Jánov synovec Andrej Balassa zase spravoval Modrý Kameň a vyženené panstvo (Považská) Bystrica v Trenčianskej stolici nedotknutej Osmanmi. Zároveň platilo, že Balassovci si porozdel'ovali dediny oboch novohradských panstiev medzi sebou, čím sa vytvoril taký stav, že niektoré dediny patrili podl'a príslušného podielu čast'ou k panstvu Divín a druhou čast'ou k Modrému Kameňu. ${ }^{43}$

Žigmund Balassa, a neskôr aj Ján Balassa, museli pri hradoch Modrý Kameň a Divín počítat' s vylepšením alebo modernizáciou ich opevnenia, pretože 21. septembra 1554 Osmani obsadili Fil'akovo a spravili z neho centrum najsevernejšieho sandžaku v Uhorsku tvoriaceho súčast' budínskeho vilájetu. Jánovi pri opevňovaní pomohli aj prijaté zákony na uhorskom sneme. Podl'a zákonného článku 23 z roku 1559 sa mali povinne šest' dní do roka poddaní z dvoch okresov Novohradskej stolice zúčastňovat' na opevňovaní hradov Šomoška, Modrý Kameň a Divín. Podl'a zákonného článku $15 \mathrm{z}$ roku 1567 sa táto povinnost' predĺžila na dvanást' dní. Zákonný článok 19 z roku 1569 nariadil, aby už poddaní z celej Novohradskej stolice pracovali na spomenutých hradoch. Uznesenia snemov potvrdil aj zákonný článok 5 z roku 1574, kde už presne definovali, aby sa na prácach podiel'ali l'udia z každej jednej porty. ${ }^{44}$

Výskumy priniesli pozoruhodné poznatky o modernizácii hradného opevnenia v priebehu 16. storočia. Ide o doklady o postupnom zdokonal'ovaní fortifikácie v pomerne krátkej dobe necelých dvoch desat'ročí. Stredoveký hrad v dobe osmanskej expanzie nevyhovoval

43 MNL - OL, f. Balassa család levéltára Az család által lajstromozott iratok (d'alej BCsLACsÁLI) (P 11), doboz 24, series IX, fascikel (d’alej fasc.) Sub NB et A; f. Balassa család levéltára Az Országos Levéltár által rendezett birtokjogi iratok (d’alej BCsLAOLÁRBI) (P 1815), doboz 4, tétel 8, rok 1792; f. Urbaria et conscriptiones (d’alej UC), fasc. 14, numero (d’alej no.) 28, pag. 36; GYULAI, É.: Žigmund Balaša, s. 344; MALINIAK, Pavol: Pomoc alebo hrozba? Kapitán banských miest Ján Balaša a jeho vzt’ahy k mešt'anom a zemanom (so zretel’om na bitku pri Sečanoch). In: Zborník z medzinárodnej konferencie Modrý Kameň, jún 2012. Rod Balašovcov v 13. až 19. storočí. zost. H. Ferencová a E. Antolová, Modrý Kameň : Slovenské národné múzeum - Múzeum bábkarských kultúr a hračiek hrad Modrý Kameň, 2013, s. 159 - 167; PÁLFFY, Géza: Účast' rodiny Balašovcov na protitureckej obrane hraníc pozdĺž riek Ipel' a Hron v 16. storočí. In: Zborník z medzinárodnej konferencie Modrý Kameň, jún 2012. Rod Balašovcov v 13. až 19. storočí. zost. H. Ferencová a E. Antolová, Modrý Kameň : Slovenské národné múzeum - Múzeum bábkarských kultúr a hračiek hrad Modrý Kameň, 2013, s. 147 - 158. Genealogická tabul'ka rodu Balassa: www.genealogy.euweb.cz/hung/balassa2.html [prístup 5. mája 2020].

${ }^{44}$ KOLOSVÁRI, Sándor - ÓVÁRI, Kelemen (eds.): Magyar törvénytár. 1526 - 1608. évi törvényczikkek. Budapest : Franklin-társulat Könyvnyomda, 1899, s. 458, 562, 564, 596, 636; PÁLFFY, G.: Účast' rodiny Balašovcov, s. 148. 
dobovým nárokom na obranu pred palnými zbraňami. Zranitel’ný bol predovšetkým z juhozápadnej strany, kde je široké sedlo prechádzajúce do okolitých svahov výškovo konkurujúcich hradu. Prestavby opevnenia sa zamerali na zosilnenie múrov a vybudovanie obranných pozícii umožňujúcich oddialenie palebných postov nepriatel'a. Prvé opatrenia realizované v rámci urýchleného budovania obrany sa sústredili na zosilnenie existujúcich hradieb a ochranu vstupu do hradu. Rozšírením staršej bránovej veže vznikla nová bránová budova s lepšou kontrolou vstupu vedeného cez priestor parkánu (obr. 5:4). Medzi dôležité obranné opatrenia patrilo zosilnenie pomerne tenkého parkánového múru a vybudovanie malého bastiónu postaveného oproti prístupu (obr. 5:6). Doplnila ich mohutná štvorboká bašta chrániaca nárožie opevnenia nad prístupovou cestou (obr. 5:10). Krátko po prvom zosilnení opevnenia vzniklo na prístupovej strane opevnené predhradie. Chránila ho masívna hradba obklopujúca priestor nádvoria rozloženého pozdíž južnej a východnej strany stredovekého hradu. Vstup do neho zabezpečovala bránová veža stojaca $v$ čele opevnenia (obr. 6:5). Podl'a striel'ní odkrytých v hradbe, obranu hradu mali zaručit' predovšetkým ručné palné zbrane. Pravdepodobne ešte pred dobytím Divína osmanskými vojskami v roku 1575 došlo k zásadnej zmene $\mathrm{v}$ charaktere opevnenia. Predhradie posilnil masívny nárožný bastión, ktorý umožnil bránit' najlepšie prístupnú stranu hradu t’ažkými palnými zbraňami. Bastión má medzi stavbami svojho typu netypický, približne štvrt'kruhový pôdorys (obr. 7:12). Ukončený bol vel'kou streleckou terasou s približne $2,5 \mathrm{~m}$ hrubou predprsňou so striel'ňami pre delá.

Expanzia moci Osmanov v druhej polovici 16. storočia dosiahla svoj najsevernejší bod v Uhorsku kapituláciou hradu Divín 28. júla 1575, ktorý územnosprávne začlenili pod fil'akovský sandžak. V rokoch 1577 - 1583 osmanskú vojenskú posádku tvorilo od 161 do 174 mužov a v rokoch 1588 - 1591 sa zmenšila na 134 až 136 mužov. Situácia sa zmenila až po vypuknutí tzv. pätnást'ročnej vojny, ked' na jej začiatku v roku 1593 cisárske vojská dobyli hrady Modrý Kameň a Divín. ${ }^{45}$

V čase okupácie Divína a Modrého Kameňa sa síce hrady dostali do rúk Osmanov, ale Balassovci považovali uvedený stav za prechodný a po smrti Jána Balassu došlo k del'be podielov patriacich $\mathrm{k}$ Modrému Kameňu, Ďarmotám (dnes Balassagyarmat) a Divínu medzi Andreja Balassu a jeho bratranca, známeho renesančného básnika Valentína Balassu (*1554 †1594), syna nebohého Jána. Bratranci si v roku 1583

\footnotetext{
${ }^{45}$ KOPČAN, Vojtech: Turecké nebezpečenstvo a Slovensko. Bratislava : VEDA, 1986, s. 72 74, 94 - 96; HEGYI, Klára: A török hódóltság várai és várkatonasága. II. kötet. Budapest : MTA Történettudományi Intézete, 2007, s. 816 - 819.
} 
podiely v panstvách uvedených troch hradov rozdelili tak, že Valentín prevzal najväčšiu čast' na panstve Divín. ${ }^{46}$

Po oslobodení Divína sa ho ujal Valentín Balassa aj so svojim mladším bratom Františkom Balassom (†1594) a v spoločne vedených vojenských operáciách obsadili na Divínskom i Modrokamenskom panstve podiely Žigmunda Balassu (†1623), syna Andreja Balassu. Informácie o tomto konflikte zanechala správa z 28. februára 1596 zachytávajúca stav uhorských hradov na južnej hranici. Podl'a nej polia a lúky patriace $\mathrm{k}$ hradu Divín spolu s lesmi stále vlastnili Osmani. V priestoroch hradu neskladovali žiadne obilie. Zaklenuté miestnosti boli v ruinálnom stave a vyzerali horšie ako samotné hradné stavby. V zlom stave sa nachádzali strechy, a ak by sa nezačali opravovat', hrozilo ich zrútenie. Ked'že obyvatelia panstva stále slúžili Osmanom, nemohli opravovat' hrady Modrý Kameň a Divín, pretože pracovali na údržbe pevnosti v Sečanoch. ${ }^{47}$

František Balassa nezanechal po sebe žiadnych potomkov a jediný Valentínov syn Ján Balassa (†1601) zomrel bezdetný. Následne sa na isté obdobie jediným vlastníkom Divína stal spomínaný Žigmund Balassa. Za jeho čias za povstania Štefana Bocskayho bol hrad hajdúchmi obsadený a skonfiškovaný v prospech povstaleckého vodcu. Pre jeho potreby 12. mája 1605 vznikol súpis majetkov na území Novohradu, medzi ktoré patrilo aj panstvo Divín. Bližšie nedatovaný popis príslušenstva hradu asi zo začiatku 17. storočia dokladal, že väčšinovým držitel'om bol Žigmund Balassa, pretože nijaký iný Balassa sa nespomínal ako spolumajitel'. Okrem Divína mal Žigmund v rukách aj hrady Modrý Kameň a (Považská) Bystrica, pričom z kontextu neskoršej vel'kej rodovej del'by v roku 1624 vyplynulo, že Žigmundovu hlavnú rezidenciu predstavoval hrad Bystrica a ned'aleký kaštiel' v Orlovom. ${ }^{48}$

Žigmund Balassa po sebe zanechal piatich synov, čo mohlo priaznivo ovplyvnit' postavenie Divína ako rezidencie, a to aj napriek jeho blízkej polohe k hraniciam s Osmanmi. Dňa 10. mája 1624 vzniklo definitívne znenie rozdelenia majetku nebohého Žigmunda. Hrad Bystrica s kaštiel'om v Orlovom si ponechala do svojej smrti Žigmundova vdova Alžbeta Zborowszká s dcérou Eufrozínou Balassovou. O hrady Modrý Kameň a Divín, kam sa prest'ahujú, sa budú starat' synovia. Tí si medzi sebou podelili aj dediny oboch novohradských panstiev. V prípade Šimona

\footnotetext{
${ }^{46}$ MNL - OL, f. BCsLACsÁLI (P 11), doboz 24, series IX, fasc. Sub NB et A. Genealogická tabul'ka rodu Balassa: www.genealogy.euweb.cz/hung/balassa2.html [prístup 5. mája 2020]. ${ }^{47}$ MNL - OL, f. UC, fasc. 14, no. 28, pag. 34, 36. Genealogická tabul'ka rodu Balassa: www. genealogy.euweb.cz/hung/balassa2.html [prístup 5. mája 2020].

${ }^{48}$ MNL - OL, f. BCsLAOLÁRBI (P 1815), doboz 3, rok 1652; f. UC, fasc. 44, no. 52, pag. 35, 41, 42, 44 - 49; fasc. 108, no. 67, pag. 1-7. Genealogická tabul'ka rodu Balassa: www. genealogy.euweb.cz/hung/balassa2.html [prístup 5. mája 2020].
} 
Balassu by sa dalo uvažovat' o tom, že by sa v budúcnosti mohol stat' výhradným majitel'om Divína, ked'že ako jediný z bratov dostal majer pod týmto hradom. Na druhej strane o nesídelnom význame Divína by svedčilo, že v nasledujúcom roku 1625 si bratia, vrátane Šimona, rozdelili obytné budovy iba na hrade Modrý Kameň a o del'be priestorov Divína sa nezmienili. Šimon si ale za svoje sídlo zvolil (Považské) Podhradie, kde si vybudoval nový kaštiel'. 49

Situáciu o nesídelnom význame Divína pre Balassovcov by vysvetl'oval neskorší dokument z roku 1631. Podl'a neho po smrti Žigmunda Balassu sa majitel'kou Divína a príslušných podielov stala Žigmundova teta Žofia Méreyová, vdova po Pavlovi Czoborovi. Po Žofiinej smrti začal o hrad Divín prejavovat' záujem Žigmundov brat Imrich st. Balassa, ktorý si rovnako ako jeho synovec Šimon Balassa postavil kaštiel' v Podhradí. Po rokovaniach sa Imrich st. so synovcom dohodol, že Šimonovi zaplatí 6650 zlatých a rozdelia si nanovo podiely v dedinách panstva Bystrica. Výslednú dohodu zapísali zástupcovia Novohradskej stolice 28. apríla 1631 pod hradom Divín. ${ }^{50}$

Získanie hradu jedným členom rodu Balassa možno podl'a nášho názoru spájat' s výstavbou alebo prestavbou renesančných obytných budov. Písomné pramene však túto hypotézu nijakým spôsobom nepodporili. I ked' hrad držal v rukách od roku 1631 Imrich st. Balassa a po jeho smrti niekedy v roku 1633 jeho syn gróf Imrich ml. Balassa (†1683), niektoré dediny panstva zostali v rukách potomkov Žigmunda Balassu a boli natrvalo pričlenené k panstvu Modrý Kameň. ${ }^{51}$

Imrich $\mathrm{ml}$. Balassa patril k popredným protiosmanským bojovníkom, ale zároveň ku kontroverzným osobnostiam doby svojou násilníckou povahou. Minimálne v rokoch 1653 - 1657 zastával post velitel'a pevnosti Ďarmoty, od roku 1653 bol cisársko-král'ovským komorníkom, v roku 1657 už patril medzi rytierov Zlatej ostrohy a vykonával aj post hlavného župana Peštianskej stolice. Dňa 3. januára 1653 ho Ferdinand III. povýšil do grófskeho stavu a v roku 1668 už patril medzi cisársko-král'ovských radcov. Imrich ml. sa pri obrane svojich záujmov neštítil žiadneho násilia, pred rokom 1666 viedol otvorený konflikt aj so svojim príbuzným grófom Valentínom Balassom, majitel'om panstva Šalgov, ktoré tvorilo aj niekdajšie panstvo Ozdín v tesnom susedstve

\footnotetext{
${ }^{49}$ MNL - OL, f. BCsLACsÁLI (P 11), doboz 10, series II, fasc. 6, no. 82; f. BCsLAOLÁRBI (P 1815), doboz 3, rok 1652.

${ }^{50}$ MNL - OL, f. BCsLACsÁLI (P 11), doboz 1, series I, fasc. VIII, no. 191; doboz 10, series II, fasc. 6, no. 99. Genealogická tabul'ka rodu Balassa: www.genealogy.euweb.cz/hung/balassa2. html [prístup 5. mája 2020]. SZLUHA, Márton: Nyitra vármegye nemes családjai II. kötet L-ZS. Budapest : Heraldika Kiadó, 2015, s. 124.

${ }^{51}$ MNL - OL, f. BCsLACsÁLI (P 11), doboz 1, series I, fasc. VI. Genealogická tabul'ka rodu Balassa: www.genealogy.euweb.cz/hung/balassa2.html [prístup 5. mája 2020].
} 
Divína. Imrich ml. sa vyhrážal poddaným na niekdajšom Ozdínskom panstve a nútil ich bránit' hrad Divín, niektorých l'udí zajal a išiel s nimi obliehat' ned'aleký hrad grófa Adama Forgácha v Haliči. ${ }^{52}$

Z čias Imricha ml. Balassu sa zachoval urbár panstva Divín z 30. marca 1661, ktorý uviedol, že na hrade sa trvale zdržiaval jeden polkoráb, teda kastelán, pätnást' hajdúchov, jeden desiatnik, jeden bubeník, jeden „czaibert"53 a traja delostrelci. Zemepanské mesto pod hradom nebolo poplatné Osmanom a preto malo na mestskej bráne šiestich hajdúchov. Pri hradnej bráne na bašte „nazývanej Polkorábova“ každú noc bdeli dvaja strážcovia, ktorí dávali pozor na signály z mesta v prípade náhleho prepadu. Strážcovia boli v očnom kontakte s jedným chlapom, ktorý býval v kostolnej veži a držal stráž. ${ }^{54}$

Neustále lavírovanie Imricha ml. Balassu medzi dodržiavaním zákonov a vernost'ou Leopoldovi I. a otvorenými vojenskými konfliktami viedlo k obliehaniu Divína a jeho vydaniu v júli 1667 . Niekedy medzi rokmi 1670 a 1673 vznikol súpis cisárom skonfiškovaných majetkov naprieč celým Uhorskom. Hodnota majetku grófa Imricha ml. Balassu dosahovala 96080 zlatých. Z toho cena samotného hradu Divín predstavovala 1440 zlatých. 55

Z obdobia správy panstva Divín Uhorskou komorou sa zachovalo niekol'ko súpisov, z ktorých iba v tom z 23. až 25. apríla 1678 zaznamenali priestory na hrade, pričom $v$ tomto čase ešte nespomínali jeho zlý stav ako v neskorších dokumentoch $\mathrm{z}$ roku 1685. Na hrade sa v roku 1678 v „bašte vedl'a kuchyne“ nachádzali sudy s kapustou, postel', v kuchyni dva ražne, jedno sito, dva medené hrnce, v „bašte zvrchu hradu“ sedem vencov cibule, hrach, pri „elés háze “56 biela múka, čel’adná múka a kamenná sol', v „pitvore nad pekárňou“ dve laná na t’ahanie vína, „na povale nad svetlicami“ mangel', sušené slivky, sušené jablká, slanina,

\footnotetext{
52 MNL - OL, f. BCsLACsÁLI (P 11), doboz 28, series XIII, fasc. AR, no. 445, rok 1657; f. BCsLAOLÁRBI (P 1815), doboz 1, tétel 1, rok 1666; doboz 3, rok 1668. FEDERMAYER, Frederik: Lippayovci zo Zomboru. Genealogický pohl'ad na vznik novej prohabsburskej aristokracie. In: Magnátske rody v našich dejinách 1526 - 1948. zost. F. Federmayer, Martin : Slovenská genealogicko-heraldická spoločnost', 2012, s. 56-58. Bližšie k osobnosti Imricha Balassu pozri: SZIRÁCSIK, Éva: Rablólovag vagy földesúr? Gróf Balassa III. Imre. Budapest : Unicus Kiadó, 2016, 136 s.

${ }^{53}$ Pravdepodobne ide o správcu zbrojnice. Za upozornenie na význam tohto slova autori d’akujú PhDr. Pavlovi Maliniakovi, PhD.

${ }^{54}$ MNL - OL, f. Zichy család (d’alej ZCs) (P 707), csomó 145, fasc. 145, no. 1. Analýze tohto urbára z hl'adiska hospodárskych a spoločenských pomerov na panstve sa venovala: SZIRÁCSIK, É.: Divínske panstvo, s. 374 - 400.

${ }^{55}$ MNL - OL, f. UC, fasc. 102, no. 1, pag. 1. SZIRÁCSIK, É.: Divínske panstvo, s. 374, 375.

${ }^{56}$ Mad’arský termín ponechávame, ked’že z našich súčasných poznatkov o vnútornom členení hradov zatial' nepoznáme najvhodnejší slovenský dobový ekvivalent. Termín označuje potravinové skladisko.
} 
dvadsat' sliepok pre kuchyňu, „v komore nad pekárňou“ pušný prach, pät' stoličiek, potrebné vybavenie k studni, ${ }^{57}$, „v rekestéšsi ${ }^{58}$ pod schodmi“ čakany, lopaty a iné náradie, „zvrchu hradu v hornej bašte“ divé jablká, $v$ „ubikácii provízora“ stôl, malý stôl, 24 drevených kresiel a dve pušky.59

$\mathrm{V}$ priebehu 17. storočia sa na hrade uskutočnilo vel'ké množstvo stavebných úprav, ktoré sa sústredili predovšetkým na modernizáciu a rozširovanie obytných budov. Stredoveké priestory južného paláca v hornom hrade boli zvýšené o d'alšie obytné podlažie so zaklenutými miestnost'ami, ktoré z vonkajšej strany prekryla zvýšená obranná hradba. Súčasne vzniká aj nové obytné krídlo postavené na východnej strane nad vstupnou bránou do hradu. Do svojich priestorov poňalo aj vnútro pril'ahlej hranolovej bašty chrániacej vstupnú bránu (obr. 7:4). Poslednou dostavbou v priestore horného hradu bol úzky trakt na severnej strane nádvoria.

Priestor predhradia popri obrannom poslaní plnil aj funkciu hospodárskeho zázemia opevneného sídla s vlastnými obytnými a prevádzkovými stavbami. V severnej časti nádvoria vznikla rozsiahla hospodárska budova zaberajúca priestor priamo pod bránovou budovou horného hradu (obr. 7:15). Jej zaklenuté pivnice využívajú staršiu obrannú priekopu. Pril'ahlá nárožná bašta sa nadstavaním nových podlaží zmenila na obytno-obrannú stavbu. Ďalšie hospodársko-obytné stavby zabrali plochu pozdĺž hradieb predhradia (obr. 7:13,14). Bezpečnost' pevnosti vdobe stavovských povstaní a pokračujúcich protiosmanských vojen mala zaistit' dostavba d'alších delostreleckých bastiónov. Opevňovacie práce sa sústredili aj na t’ažko prístupnú severozápadnú stranu opevnenia. Staršiu hradbu na okraji strmého zrázu zosilnili primurovaním nevel'kého bastiónu, ktorý mal kontrolovat' prístupovú cestu smerujúcu od kostola v podhradskej obci smerom k hradu (obr. 7:7). Jednu z posledných stavebných aktivít na hrade predstavuje adaptácia bastiónu pri vstupnej bráne. Lepšiu obranyschopnost' hradu chceli docielit’ výrazným zvýšením streleckej plošiny. Zároveň s tým plánovali obranu hradu umocnit' moderným bastiónom hrotitého tvaru (obr. 7:16). Podl'a nálezov z výskumu je zjavné, že tento zamýšl'aný bastión nikdy nedokončili v plánovanom rozsahu.

Povstanie Imricha Thökölyho prinieslo pre hrad definitívny koniec údržby a postupnú premenu na zrúcaninu. Úlohu správneho centra prevzal opevnený kaštiel' pod hradom. Podl'a informácie Uhorskej komory z 13. novembra 1685 zaslanej Leopoldovi I. hrad, kaštiel' i samotné ze-

\footnotetext{
${ }^{57} \mathrm{MNL}$ - OL, f. UC, fasc. 87, no. 2 b), pag. 2, 5, 6, 17.

58 Dobové v slovenčine zaužívané podstatné meno označovalo menšiu miestnost' ohradenú od ostatných priestorov drevenými stenami.

${ }^{59} \mathrm{MNL}-\mathrm{OL}$, f. UC, fasc. 87, no. 2 b), pag. 7.
} 
mepanské mesto Divín boli v roku 1683 vypálené a porúcané v t’ažkých vojnových časoch. Kaštiel' a majer sa budú musiet' opravit'. Obnovu hradu považovali za zbytočnú a situácia sa nezmenila ani po príchode nového majitel'a grófa Štefana Zichyho $(* 1616+1693) .60$

Štefan Zichy získal panstvo Divín postupne. Najprv mu Leopold I. 13. novembra 1685 daroval iba polovicu panstva ako konfiškát po nevernom Imrichovi ml. Balassovi a pripojil $\mathrm{k}$ tomu aj podiely bezdetného Valentína Balassu. Za udelené majetky Štefan zaplatil 35000 rýnskych zlatých. V nasledujúcom roku Štefan uhradil d'alších 18000 rýnskych zlatých a následne Leopold I. 16. júla 1686 daroval celé hradné panstvo Štefanovi Zichymu a jeho manželke Magdaléne Amadeovej. Nezáujem Zichyovcov o údržbu hradu vyjadrovali rozsiahle súpisy prináležitostí celého panstva Divín z roku 1759 a 1812, kde hrad na rozdiel od kaštiel'a vôbec neopisovali. ${ }^{61}$

\section{PRÍlOHA}

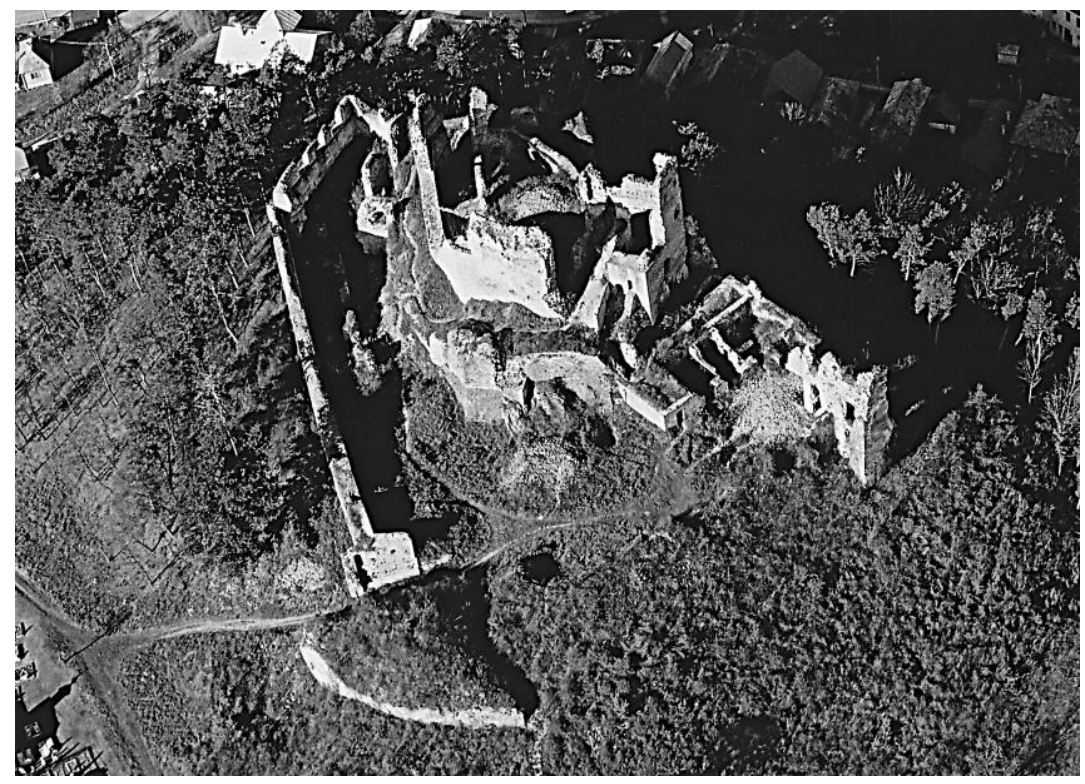

Obr. 1. Letecký pohl’ad na hrad. Foto: Václav Hanuliak.

\footnotetext{
${ }^{60}$ MNL - OL, f. BCsLAOLÁRBI (P 1815), doboz 1, tétel 1, rok 1685. Genealogická tabul'ka rodu Zichy: www.genealogy.euweb.cz/hung/zichy2.html [prístup 5. mája 2020].

${ }^{61}$ MNL - OL, f. ZCs (P 707), csomó 135, fasc. 175, no. 18; csomó 147, fasc. 183, no. 12a; csomó 147, fasc. 184, no. 18; f. MKL, LR 18, pag. 402 - 404.
} 


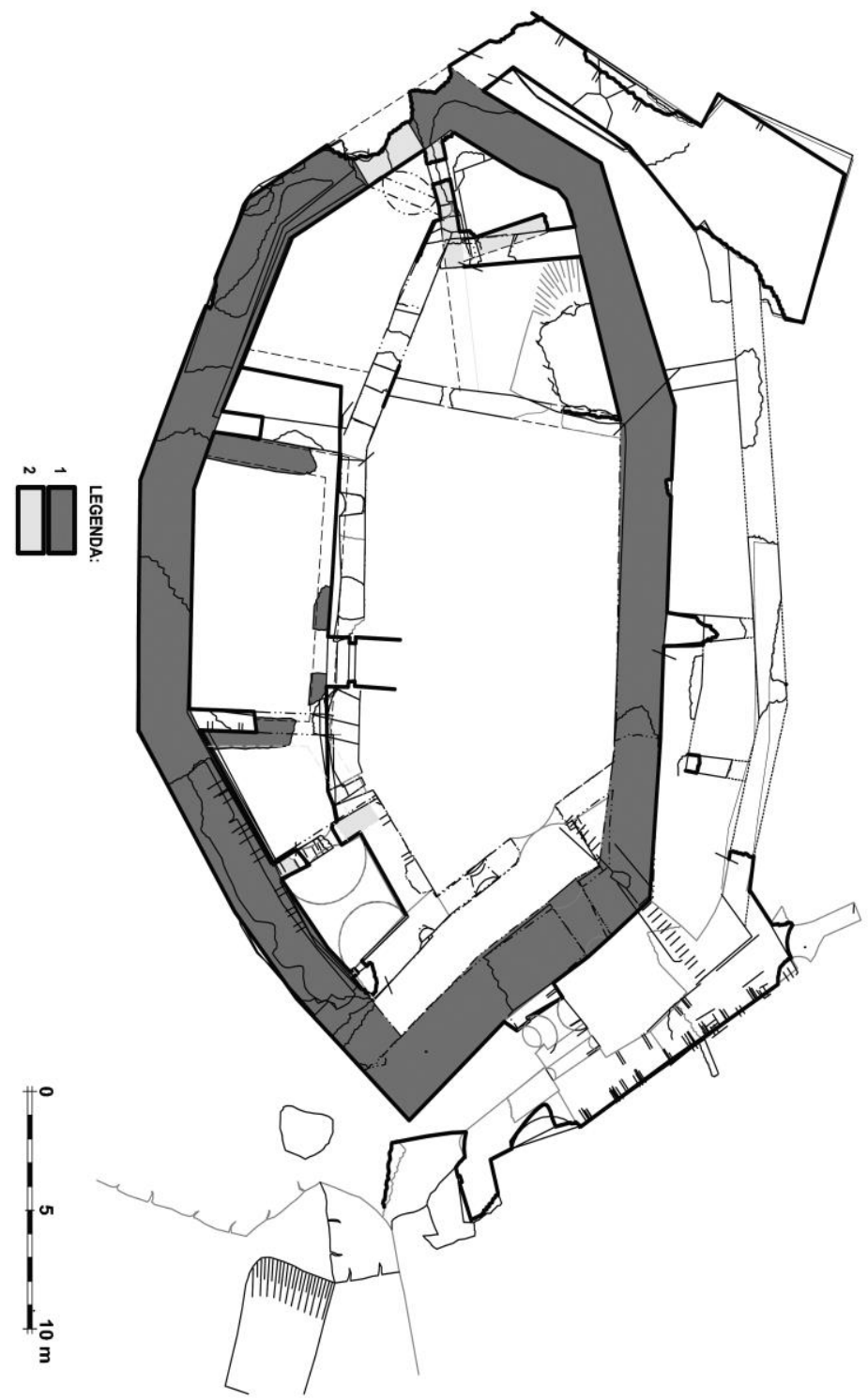

Obr. 2. Pôdorys horného hradu s vyznačením stredovekých murív. 1 - hradba a palác zo začiatku 14. storočia, 2 - mladšia prestavba zo 14 . storočia. 


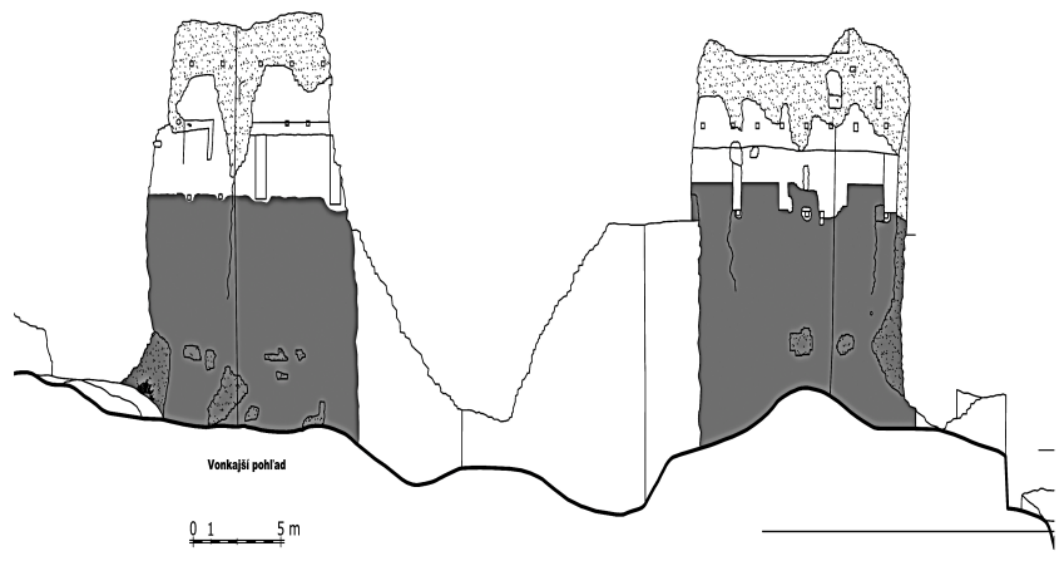

Obr. 3. Pohl’ad na horný hrad s označením zachovanej stredovekej hradby.

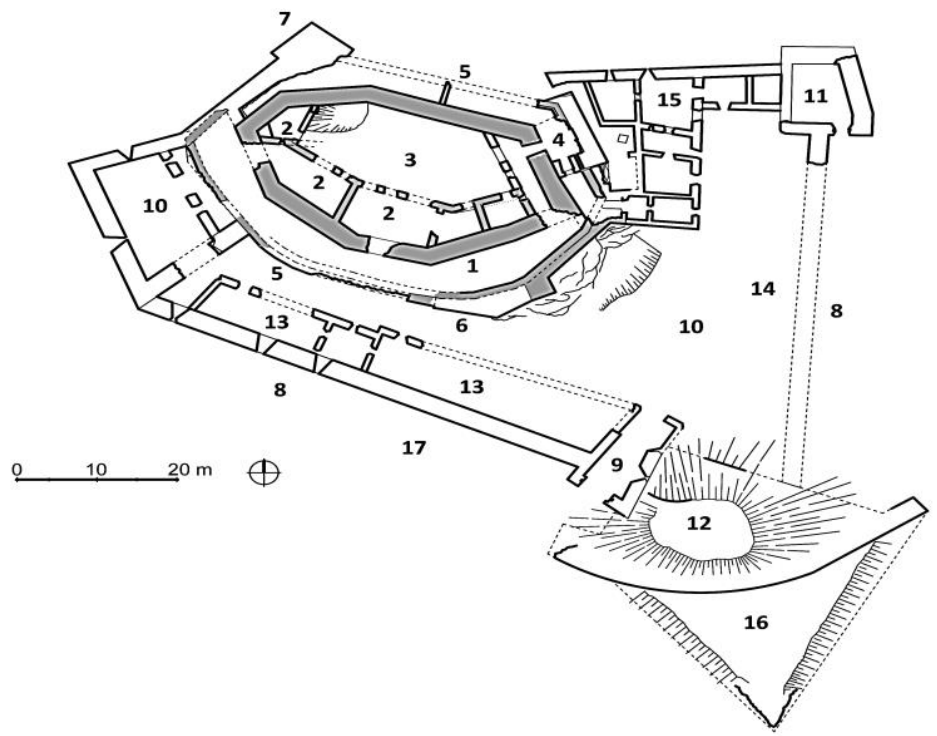

Obr. 4. Pôdorys hradu s označením rozsahu hradu na konci stredoveku. 


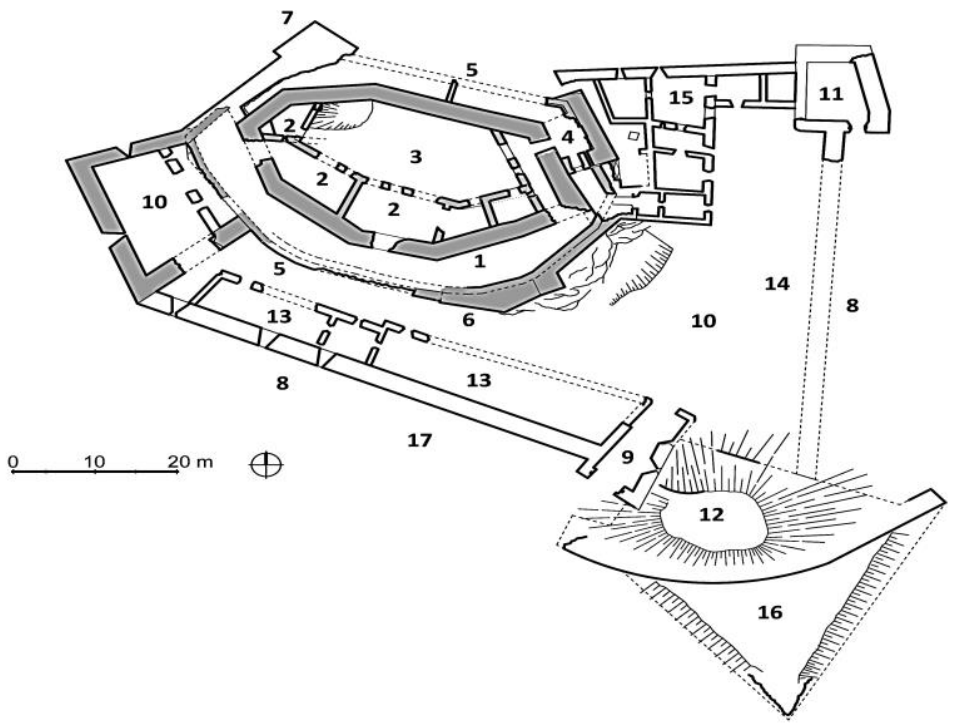

Obr. 5. Pôdorys hradu s označením rozsahu hradu po prvých opevňovacích prácach v 16. storočí.

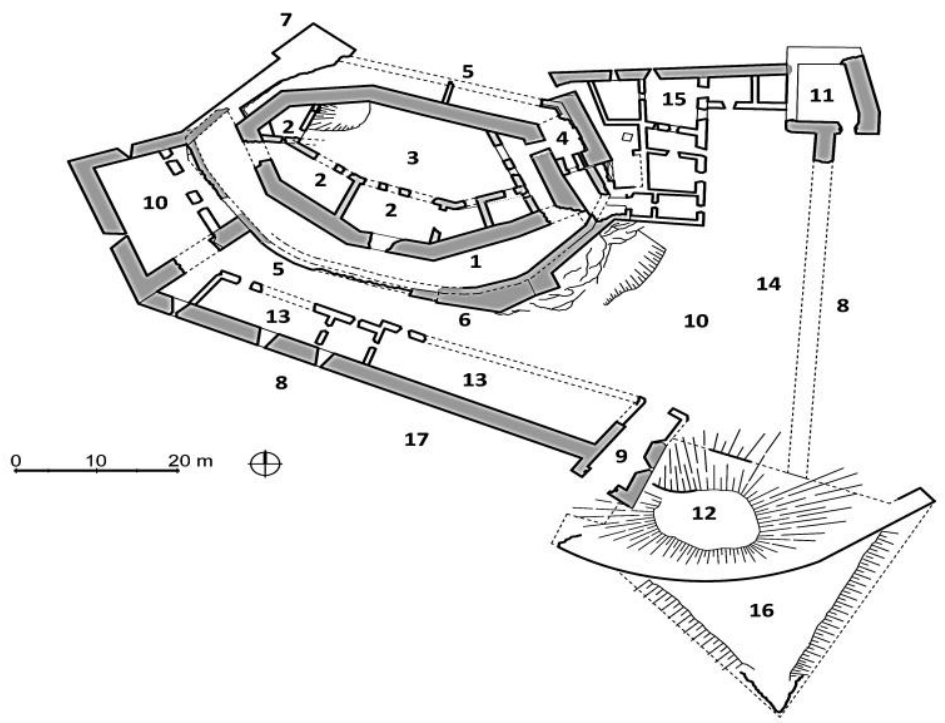

Obr. 6. Pôdorys hradu s označením rozsahu hradu v 3. štvrtine 16. storočia. 
Tomáš Janura - Michal Šimkovic - Eva Fottová

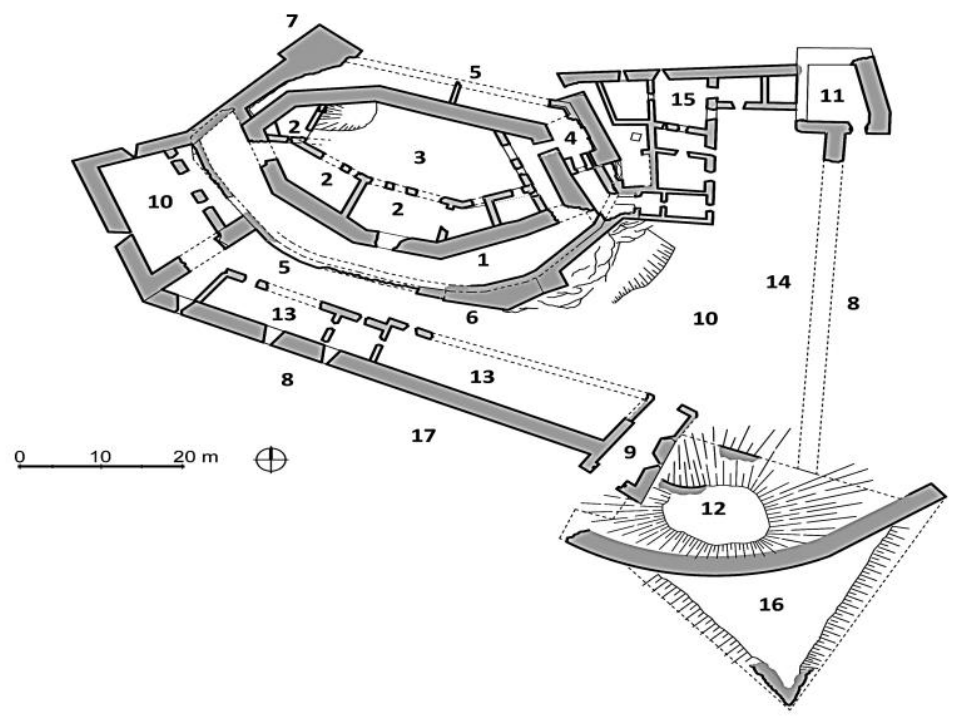

Obr. 7. Pôdorys hradu s označením rozsahu hradu v 17. storočí. 